\title{
Neuroscience in Nazi Europe Part I: Eugenics, Human Experimentation, and Mass Murder
}

\author{
Lawrence A. Zeidman
}

\begin{abstract}
The Nazi regime in Germany from 1933 to 1945 waged a veritable war throughout Europe to eliminate neurologic disease from the gene pool. Fueled by eugenic policies on racial hygiene, the Nazis first undertook a sterilization campaign against "mental defectives," which included neurologic patients with epilepsy and other disorders, as well as psychiatric patients. From 1939-41 the Nazis instead resorted to "euthanasia" of many of the same patients. Some neuroscientists were collaborators in this program, using patients for research, or using extracted brains following their murder. Other reviews have focused on Hallervorden, Spatz, Schaltenbrand, Scherer, and Gross, but in this review the focus is on neuroscientists not well described in the neurology literature, including Scholz, Ostertag, Schneider, Nachtsheim, and von Weizsäcker. Only by understanding the actions of neuroscientists during this dark period can we learn from the slippery slope down which they traveled, and prevent history from repeating itself.
\end{abstract}

\begin{abstract}
RÉSUMÉ: Neuroscience en Europe sous domination nazie : l'eugénisme, l'expérimentation humaine et le meurtre de masse. Le régime nazi, au pouvoir de 1933 à 1945 en Allemagne, a mené une véritable guerre à travers l'Europe afin d'éliminer la maladie neurologique du patrimoine génétique. Les Nazis, exaltés par des politiques eugéniques, ont d'abord entrepris une campagne de stérilisation des "déficients mentaux", dont des patients atteints de maladies neurologiques comme l'épilepsie, et de patients atteints de maladies psychiatriques. De 1939 à 1941, les Nazis ont eu recours à l'"euthanasie" de plusieurs de ces patients. Des neuroscientifiques ont collaboré à ce programme et ont utilisé certains patients ou le cerveau prélevé après leur meurtre pour la recherche. Des revues ont porté sur Hallervorden, Spatz, Schaltenbrand, Scherer et Gross. Cette revue porte sur des neuroscientifiques qui peu connus dans la littérature neurologique, dont Scholz, Ostertag, Schneider, Nachtsheim et von Weizsäcker. La compréhension des actes des neuroscientifiques pendant cette époque obscure peut nous permettre d'apprendre des dérapage du parcours qu'ils ont emprunté et empêcher que l'histoire ne se répète.
\end{abstract}

Can. J. Neurol. Sci. 2011; 38: 696-703

The 1930's was a time of great upheaval in German neuroscience. ${ }^{\mathrm{a}}$ The reign of Hitler and the Nazi regime beginning in 1933 brought with it the expulsion or exodus of many of the great German neurologists and neuroscientists of the early 20th century, including Franz Josef Kallman, Friedrich Heinrich Lewy, Max Bielschowsky, Alfred Bielschowsky, Michael Balint, Ilya Mark Scheinker, Joseph Gerstmann, Robert Wartenberg, and Adolph Wallenberg. ${ }^{1-3}$ Some were stripped of their professional titles including Adolf Heidenhain, Ernst Moro, ${ }^{\mathrm{C}}$ and Ernst Sträussler. ${ }^{2}$ Many of these scientists were Jewish, but some left or were dismissed for political reasons. ${ }^{1-3}$ Some others who stayed were murdered by the Nazis, including Ludwig Pick, Arthur Simons, Wladyslaw Sterling, and Lucja Frey. ${ }^{1-3}$ Additionally, some courageous neuroscientists resisted the Nazi regime, including Johannes Cassianus Pompe, ${ }^{\mathrm{d}}$ Walther Spielmeyer, Jules Tinel, and Cécile and Oskar Vogt. ${ }^{2,3}$ Yet other neuroscientists actively collaborated with the Nazis, and were heavily influenced by the ideas of eugenics that were popular in the first half of the 20th century and justified Nazi policies on "racial hygiene."1-3

The Nazis saw a precedent in the United States (US) for sterilization and human experimentation on those they deemed of lesser value to humanity. ${ }^{1}$ There were approximately 400000 sterilized under the 1933 Nazi Sterilization law, of whom 80$96 \%$ were cases of "congenital feeblemindedness," schizophrenia, and hereditary epilepsy. There were also cases of

see footnote for ${ }^{a-d}$ on following page

From the University of Illinois at Chicago, Department of Neurology and Rehabilitation (M/C 796), Neuropsychiatric Institute, Chicago, Illinois, USA.

Received December 7, 2010. FinAl Revisions SubMitTEd APRIL 12, 2011 Correspondence to: Lawrence A. Zeidman, University of Illinois at Chicago, Department of Neurology and Rehabilitation (M/C 796), Neuropsychiatric Institute, 912 S. Wood Street, Room 855N, Chicago, Illinois, 60612-7330, USA 
bipolar disorder, Huntington disease, major brain malformations, congenital blindness, congenital severe hearing loss, chronic alcoholism,' pre-senile and senile dementia, encephalitis, poliomyelitis, "therapy-resistant paralysis," multiple sclerosis, and Parkinson's disease..$^{4-5}$ Pediatricians, psychiatrists, and neurologists were most involved in reporting such individuals to the genetic health courts. ${ }^{6-7}$ The Nazis became convinced an active "euthanasia" program would be more economical than sterilization, as well as freeing up hospital beds for soldiers from the war front after the onset of World War II in September, 1939. Adolf Hitler stated to his subordinates a few months prior to the inception of euthanasia that, "he considered it proper that the "life unworthy of life' of severely mentally ill persons be eliminated by actions that bring about death." In this way, "a certain saving in hospitals, doctors, and nursing personnel could be brought about." ${ }^{8}$ Between 1939 and 1941 the Nazis ran both the children's "euthanasia" program, and the adult "Action T4" program. The name for the adult program came from the address of the T4 headquarters at an anonymous suburban villa at Tiergartenstrasse 4 in Berlin, intentionally geographically distant from the Chancellery of the Fuhrer to obscure its administrative connection..$^{5}$ It was calculated that 70273 adult patients and thousands more children were killed, primarily by gassing, starvation, or lethal injection. After the program "officially" ended in 1941 following protests from family members of the victims, the Catholic Church, and others, the program continued secretly and up to 275000 overall may have been killed by 1945. ${ }^{1,4,6,9}$

Much has been written in the neurology literature of the past two decades concerning the sordid activities during the Holocaust of two pre-eminent German neuropathologists, Julius Hallervorden (1882-1965) and Hugo Spatz (1888-1969). These two, in 1922, described the first case of what is now called pantothenate kinase-associated neurodegeneration (PKAN), a condition at the time given the eponym "Hallervorden-Spatz Disease." There has been mixed opinion about whether the two deserve an eponym given that, between 1939 and 1941 at the Kaiser Wilhelm Institute (KWI) for Brain Research in Berlin, they actively collected and dissected brains of T4 victims. ${ }^{1-4,6,7,9}$ Hallervorden collected 697 brains himself, and 2097 brains overall were collected from the various brain research centers. ${ }^{4}$ Also previously described are the exploits of German neurologist Georg Schaltenbrand (1897-1979), ,,7 German neuropathologist Hans Joachim Scherer (1906-1945) (Figure $1),{ }^{1-3}$ and Austrian pediatric neurologist Heinrich Gross (19152005). ${ }^{2}$ Scherer was the first to distinguish between primary and secondary glioblastomas, and co-described cerebrotendinous xanthomatosis (Van Bogaert-Scherer-Epstein Syndrome). At the

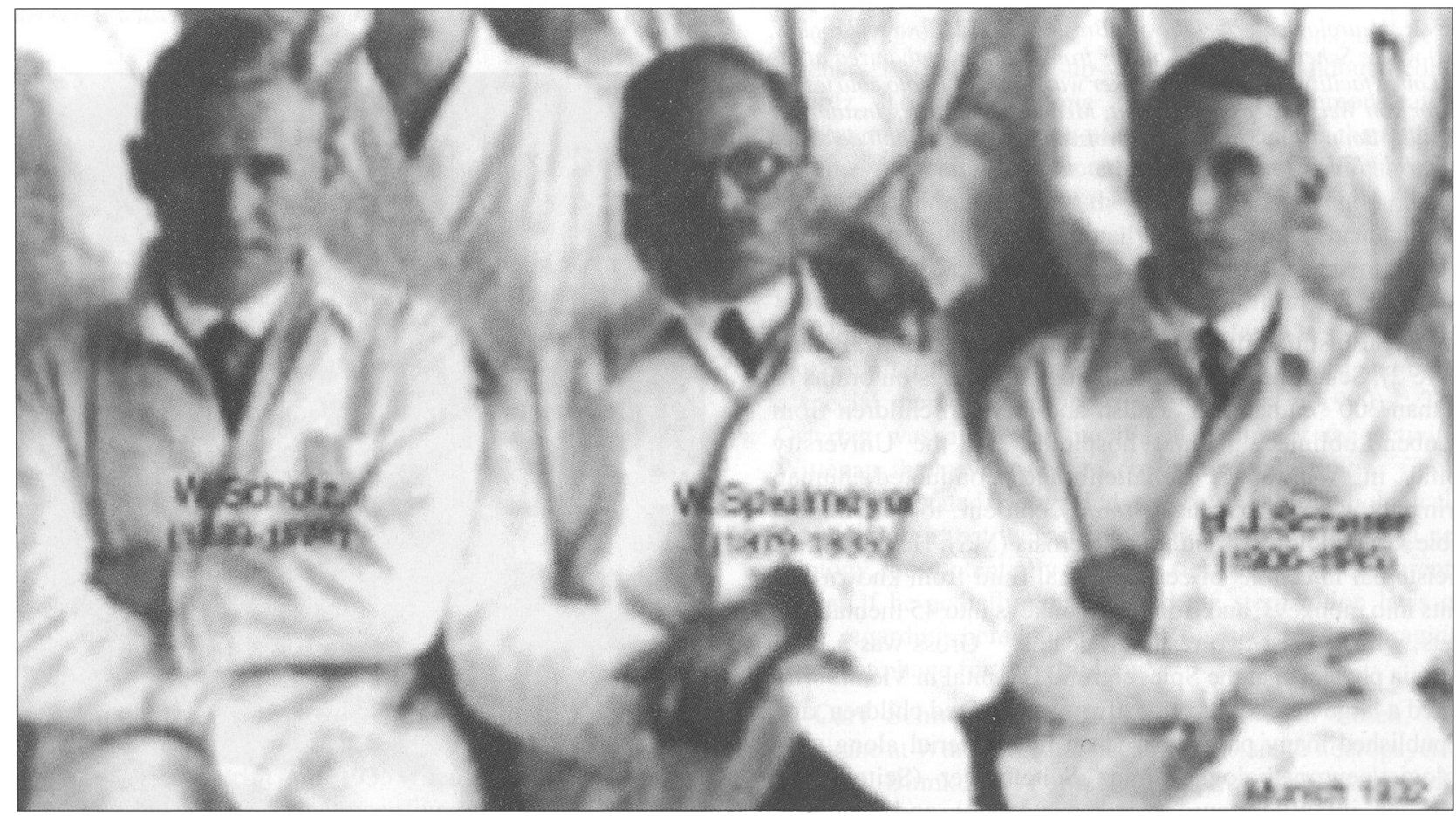

Figure 1: Willibald Scholz, Walther Spielmeyer, and Hans Joachim Scherer at the German Research Institute of Psychiatry, Munich, 1932. Photo published with permission from John Wiley and Sons, Inc.

\footnotetext{
"-The term neuroscience is a more modern term used here for expediency to describe the combination of neuropathologists, clinical neurologists, and neuropsychiatrists discussed in this paper, though the term didn't exist in the 1930's and 40's. 'b-This Bielschowsky was an ophthalmologist known for Bielschowky's sign (characteristic head posture with trochlear nerve palsy). ${ }^{2}$-Moro, famous for the Moro or startle reflex of infants seen in first 3 months of life, was a pediatrician. ${ }^{2}{ }^{2}$-Pompe was a Dutch pathologist who discovered Type II glycogen storage disease (Pompe disease, acid maltase deficiency, or 1-4 alpha glucosidase deficiency), with myopathy being a prominent symptom. ${ }^{2}$
} 


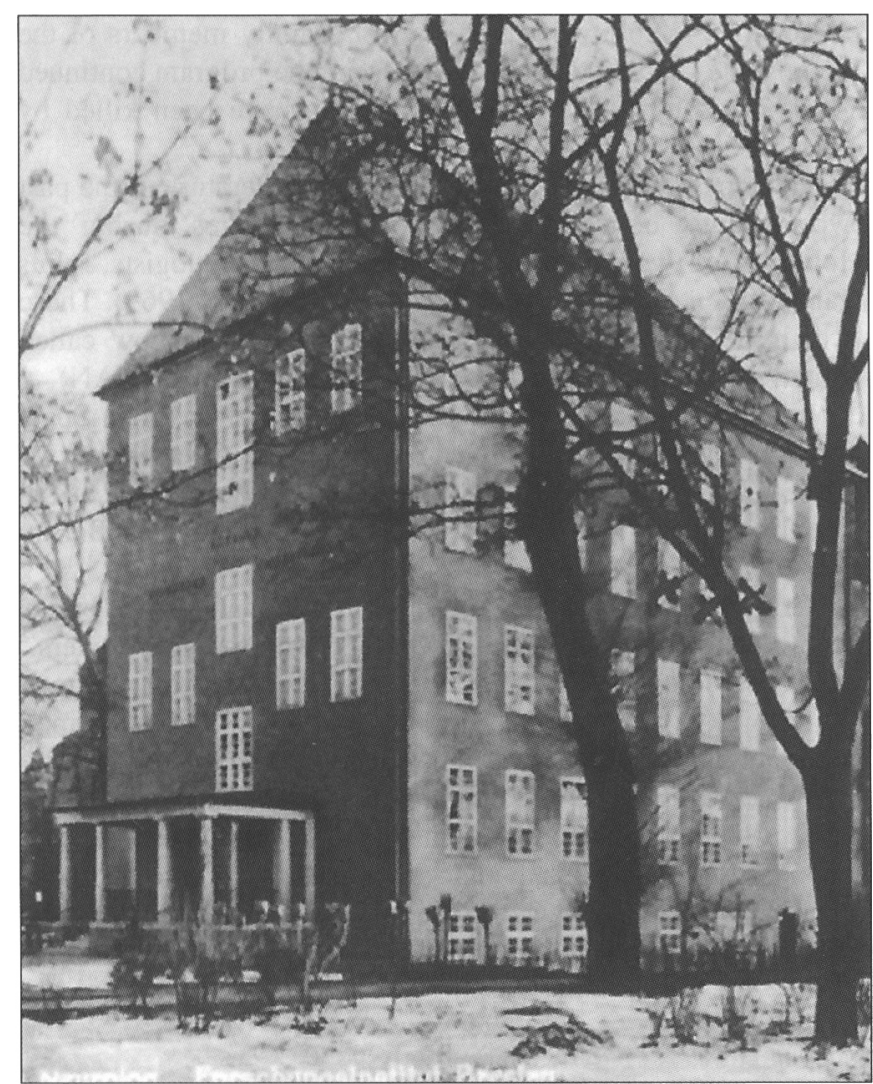

Figure 2: Neurological Institute at Breslau, Silesia (now Wroclaw, Poland) where Scherer dissected brains from children euthanized at the nearly Loben facility, and von Weizsäcker was director. Photo courtesy of the Viktor von Weizsäcker Gesellschaft, Medizinhistorisches Institut der Universität Bonn (http://viktor-von-weizsaecker-gesellschaft.deltexte_ mehr.php?id=13\&sID=3).

Neurological Institute in Breslau, Silesia (now Wroclaw, Poland - Figure 2), Scherer conducted pathological studies on brains of more than 300 "euthanized" Polish and German children from the Loben/Lubliniecz mental hospital. ${ }^{1-3}$ At the University Hospital in Würzburg, Schaltenbrand conducted human experiments, without patient or family consent, to determine a possible viral etiology of multiple sclerosis (MS). He performed intra-cisternal injections of cerebrospinal fluid from known MS patients into monkeys, and from the monkeys into 45 mentally ill patients, with at least two resultant deaths. ${ }^{4,7}$ Gross was a Nazi euthanasia physician at the Spiegelgrund Hospital in Vienna who collected a large number of brains from euthanized children, and later published many papers based on this material along with neurologist/neuropathologist Franz Seitelberger (Seitelberger disease, or infantile neuroaxonal dystrophy) and pediatric neurologist Andreas Rett (Rett syndrome). ${ }^{2}$

Less well described in the neurology literature are the "exploits" of several other neuroscientists who collaborated with the Nazis, including Willibald Oscar Scholz (Figure 1), Berthold Ostertag, Carl Schneider, Hans Nachtsheim (Figure 3), and Viktor von Weizsäcker (Figure 4). Indeed Hitler waged a veritable "war" against these neurologic and psychiatric patients, and his "soldiers" unfortunately in many cases were the very neuroscientists who should have been protecting them and treating them (Table 1).

\section{Methods}

Names of the above scientists were obtained from various review articles and books written on the topic. The website www.whonamedit.com was helpful in searching for additional names and references, as was the Dictionary of Medical Eponyms. ${ }^{10}$

\section{RESULTS}

Willibald Oscar Scholz (1889-1971) He collaborated with neuropathologist Max Bielschowsky and neurologist Richard Henneberg to describe one form of metachromatic leukodystrophy, Scholz-Bielschowsky-Henneberg disease. ${ }^{10}$ Scholz obtained his doctoral degree in 1914 at Jena, and later became head physician at the Leipzig psychiatric and nerve clinic. He succeeded Walther Spielmeyer to direct the German Research Institute for Psychiatry in Munich following Spielmeyer's death in 1935, and would remain director until 1961. His work concerned both clinical neurology and psychiatry, as well as neuropathology. Scholz's Institute

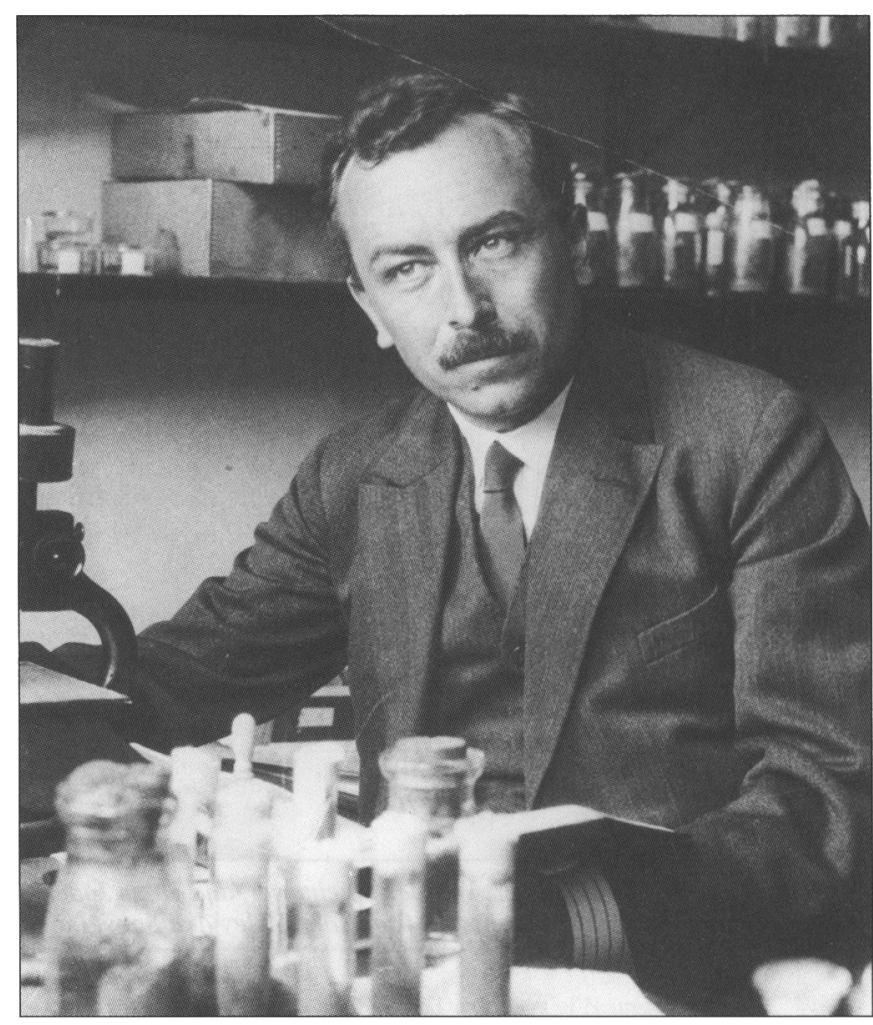

Figure 3: Professor Hans Nachtsheim in his laboratory, around 1931. Photo published with permission from the Archiv der Max-PlanckGesellschaft, Berlin-Dahlem. 


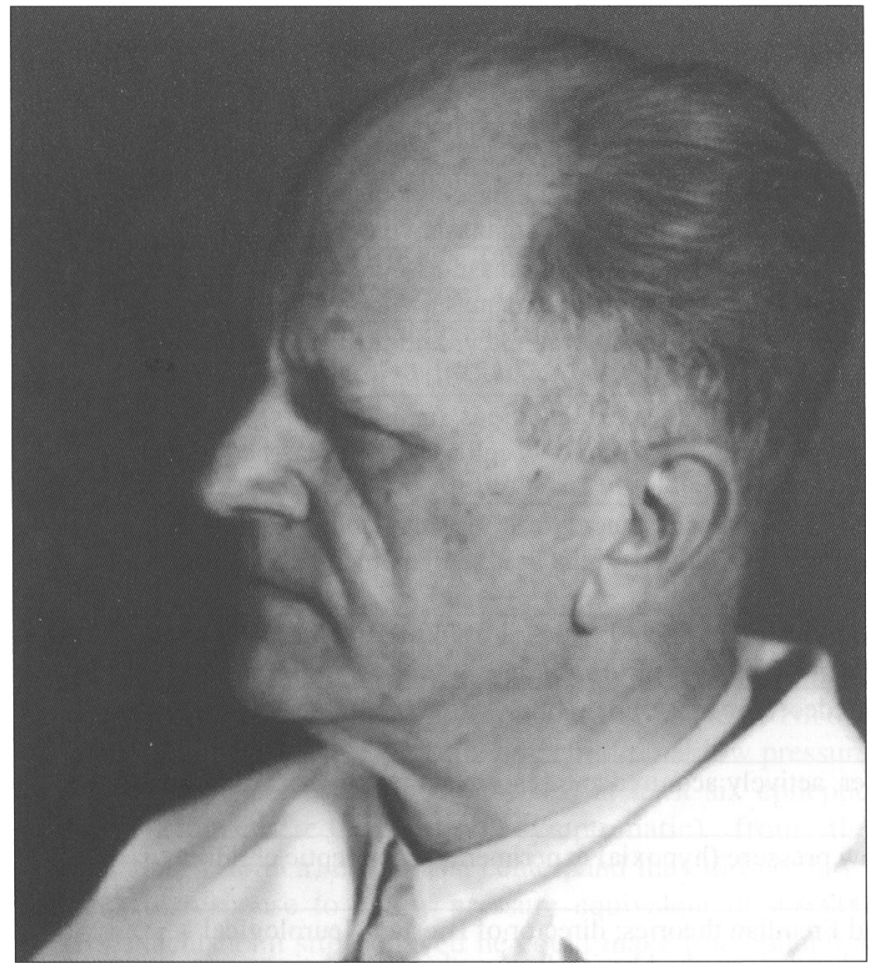

Figure 4: Viktor von Weizsäcker sometime between 1942 and 1944. Photo courtesy of the Viktor von Weizsäcker Gesellschaft, Medizinhistorisches Institut der Universität Bonn (http://viktor-vonweizsaecker-gesellschaft.de/texte_mehr.php?id=13\&sID=3).

participated in brain research on T4 euthanasia victims. ${ }^{11}$ At least 194 victim brains were studied, and at least 11 papers were published based on this research. Scholz was main author and editor of Volume 13, focusing on neuropathology, of the 1956 Handbuch der speziellen Pathologischen Anatomie und Histologie, which frequently features T4 cases. ${ }^{4}$

Berthold Ostertag (1895-1975) A neuropathologist at the Rudolf Virchow Hospital in Berlin, and was a contemporary and colleague of Julius Hallervorden.,12 Ostertag came from an established bourgeois family, was a member of the SA (Sturm Abteilung, Nazi stormtroopers also known as the "brown shirts"), and opportunistically used Nazi authority to advance his career. ${ }^{13}$ For example, he reportedly marched into the office of his Jewish colleague and friend Pathology Chief Professor Rudolf Jaffé at Berlin's Moabit Hospital in full SA captain uniform and had Jaffé expelled in order to take his position. ${ }^{14} \mathrm{He}$ did not get along with Oskar Vogt, who was director of the KWI for brain research in Berlin until 1935 when Hugo Spatz replaced him. The two had an active feud regarding Vogt's accusation that Ostertag was behind a Nazi raid on the KWI in March 1933, which offended Ostertag and he challenged Vogt to a pistol duel. Vogt declined the duel stating that Ostertag lacked the moral standards to demand the "satisfaction."13 Ostertag also defended Jewish colleague Max Bielschowsky (in contrast to earlier persecution of Jaffé) simply to resist and attack Vogt, who did

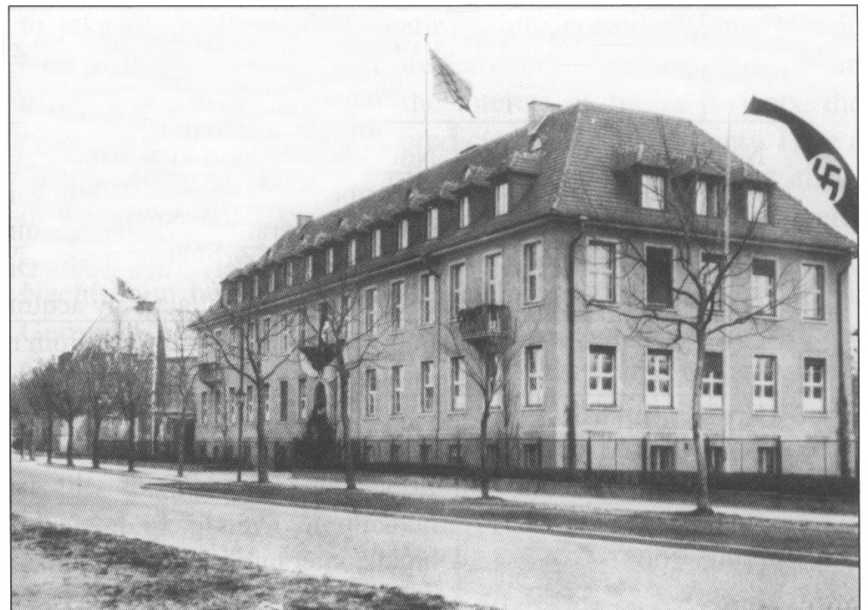

Figure 5: The Kaiser Wilhelm Institute for Anthropology, Human Heredity, and Eugenics in Berlin during the Nazi era. Photo published with permission from the Archiv der Max-Planck-Gesellschaft, BerlinDahlem.

not get along with Bielschowsky. ${ }^{14}$ A series of "honor panels" at the Institute concluded that the feud between Ostertag and Vogt was a "misunderstanding," though Ostertag continued to attack Vogt and may have written an anonymous article in a Nazi paper in 1937 about Vogt being a "Bolshevik" supporter. ${ }^{13}$

Ostertag's specialty was brain malformations, and he wrote extensively on this in a sub-volume of the Handbuch edited by Scholz. This sub-volume more clearly demonstrates the involvement and inclusion of euthanasia victims than other subvolumes. ${ }^{4}$ Ostertag conducted post mortem examinations on at least 106 children killed at the Berlin-Wittenau child euthanasia facility. These children typically died after air encephalography was performed as part of an irresponsible experiment. ${ }^{14}$ Ostertag brought part of the pathology collection from those children to the University of Tübingen Institute for Brain Research where he worked after the war (the collection was removed and buried in a special memorial service to the victims in 1990). ${ }^{14}$ Though Ostertag was aware of the illegal nature of the activities at Wittenau, he never tried to cover up the activities from that period. He stated he wanted to prove neuropathologically in these children that their mental illnesses did not have a genetic etiology, thus potentially avoiding sterilization of the parents. He felt as if he actually counteracted the sterilization laws of the time regarding hereditary mental disease, by encouraging the parents to have further children. ${ }^{14}$

Carl Schneider (1891-1946) - Born in Posen, studied medicine at Würzburg, and became assistant to neuropsychiatrist Oswald Bumke at Leipzig. He published extensively on schizophrenia, and was involved in eugenics. He was a Nazi Party member beginning in 1932 and leader of the Racial Political Office in Baden. ${ }^{5}$ He was chief at the Bethel epileptic asylum until 1933, where he reportedly demonstrated much empathy to his epileptic patients. He was very sensitive and "detested force and cold routine," often permitting psychiatrists to have lunch with patients. ${ }^{15}$ In 1934 he moved on to become 


\begin{tabular}{|c|c|}
\hline Neuroscientist & Notoriety and crimes committed \\
\hline $\begin{array}{l}\text { Julius Hallervorden } \\
(1882-1965)\end{array}$ & $\begin{array}{l}\text { Described "Hallervorden-Spatz Disease," now called pantothenate kinase-associated } \\
\text { neurodegeneration; actively acquired and researched brains from euthanasia victims }\end{array}$ \\
\hline $\begin{array}{l}\text { Hugo Spatz } \\
(1888-1969)\end{array}$ & $\begin{array}{l}\text { Described "Hallervorden-Spatz Disease," now called pantothenate kinase-associated } \\
\text { neurodegeneration; actively acquired and researched brains from euthanasia victims }\end{array}$ \\
\hline $\begin{array}{l}\text { Georg Schaltenbrand } \\
(1897-1979)\end{array}$ & $\begin{array}{l}\text { Injected cerebrospinal fluid from multiple sclerosis patients into monkeys and then from monkeys } \\
\text { into mental hospital patients to study possible viral etiology }\end{array}$ \\
\hline $\begin{array}{l}\text { Hans Joachim Scherer } \\
(1906-1945)\end{array}$ & $\begin{array}{l}\text { Co-described Van Bogaert-Scherer-Epstein Syndrome (cerebrotendinous xanthomatosis) and first to } \\
\text { distinguish between primary and secondary glioblastomas; actively acquired and researched brains } \\
\text { from euthanasia victims }\end{array}$ \\
\hline $\begin{array}{l}\text { Heinrich Gross } \\
(1905-2005)\end{array}$ & $\begin{array}{l}\text { Directly involved in children's "euthanasia" at Vienna's Spiegelgrund Hospital and collection of their } \\
\text { brains; later published papers with eponymous neurologists Franz Seitelberger and Andreas Rett } \\
\text { using those brains }\end{array}$ \\
\hline $\begin{array}{l}\text { Willibald Oscar Scholz } \\
(1889-1971)\end{array}$ & $\begin{array}{l}\text { Described one form of metachromatic leukodystrophy, Scholz-Bielschowsky-Henneberg disease; } \\
\text { actively acquired and researched brains from euthanasia victims }\end{array}$ \\
\hline $\begin{array}{l}\text { Berthold Ostertag } \\
(1895-1975)\end{array}$ & $\begin{array}{l}\text { Member of the Nazi SA faction, ousted predecessor in Berlin, actively acquired and researched brains } \\
\text { from euthanasia victims }\end{array}$ \\
\hline $\begin{array}{l}\text { Carl Schneider } \\
(1891-1946)\end{array}$ & $\begin{array}{l}\text { Nazi party member and lead T4 researcher, actively acquired and researched brains from euthanasia } \\
\text { victims }\end{array}$ \\
\hline $\begin{array}{l}\text { Hans Nachtsheim } \\
(1890-1979)\end{array}$ & $\begin{array}{l}\text { Famous German geneticist; conducted low pressure (hypoxia) experiments on epileptic children to } \\
\text { induce seizures }\end{array}$ \\
\hline $\begin{array}{l}\text { Viktor von Weizsäcker } \\
(1886-1957)\end{array}$ & $\begin{array}{l}\text { Supporter of psychosomatic medicine and Freudian theories; director of Breslau Neurological } \\
\text { Institute where neuropathologists acquired and researched brains from euthanasia victims }\end{array}$ \\
\hline
\end{tabular}

Chair of Psychiatry and Neurology at Heidelberg University. Schneider was also a proponent of "work therapy" for schizophrenic patients, but as he become more indoctrinated by Nazi ideology, he eventually pushed that idea aside to "empathically" end suffering of his patients and strengthen the race. ${ }^{15}$ This professor was Machiavellian in his beliefs on the use of brains from murdered T4 victims, and wrote that "The opportunity should not be lost to use it [Action T4] for research on mental diseases or their combat and in particular their therapy and prevention." $\mathrm{He}$ had grandiose plans for a vast research institute to study the hereditary causes of "idiocy," and he did initiate some of this work after obtaining significant funding. ${ }^{15}$ In 1942 , he wrote "In the anatomical department, the majority of the brains sent us from the Eichberg [a T4 facility] institution were examined. New and surprising findings constantly emerged, as well as disturbances which had never before been described. Only the continuation of these investigations can ensure further information; thus we urgently request a greater number of brains of idiots and severely feeble-minded patients." 12 Beside research done by Schneider's assistants on the "brain histopathology of idiots," work was done on "the differences between induced and spontaneous seizures in humans," "hydrogen experiments on patients with convulsive disorders, including idiots," "constitutional types in exogenous convulsive disorders, including head injuries suffered in combat," and "prevention of vertebral fractures in cases of convulsive shock." 12 Indeed, Schneider and Hallervorden were most zealous and ambitious in "harvesting" brains from T4 victims. ${ }^{16}$ Schneider was the T4 lead researcher, and his clinic was the lead center for the research associated with the killing program. ${ }^{16} \mathrm{He}$ eventually committed suicide in 1946 before he could be tried at the Nuremberg Medical Crimes Trial. ${ }^{1,12}$

Hans Nachtsheim (1890-1979) - Born in Koblenz, he studied zoology and genetics and received his $\mathrm{PhD}$ from the University of Munich in 1913. In 1926 he studied in the US at Columbia University on a Rockefeller fellowship, and it was around this time he began to espouse the idea of sterilization on eugenic grounds. ${ }^{17-18}$ In1941 he became head of the KWI Experimental Hereditary Pathology department at the KWI for Anthropology, Human Heredity, and Eugenics in Berlin (Figure 5). Nachtsheim revealed in rabbits the existence of a recessive epilepsy allele, and in low pressure and electric experiments showed that any animal could have seizures. He thought cerebral hypoxemia might induce vasospasm and induce spontaneous seizures. Age and genetics, he thought, played a role in the threshold for spontaneous seizures. In the 1930's psychiatrists wondered if the anti-psychotic drug Cardiazol (Metrazol in the US) could be used to diagnose hereditary epilepsy. They thought a hereditary epileptic would have seizures at a lower dose of Cardiazol than a non-epileptic or a symptomatic epileptic, and then could be compulsorily sterilized. Nachtsheim believed that Cardiazol should be tested in this regard in rabbits, with much simpler genotypes, before humans, but on testing rabbits he found Cardiazol to be of only limited diagnostic value. ${ }^{18}$ 
In 1943, he attempted to induce seizures by hypoxia through low pressure experiments in children with epilepsy, which he felt would reflect the different response to hypoxia in young and old rabbits he had seen earlier. ${ }^{18}$ Previous experiments by J. Gremmler, a junior physician at the Brain Research Office of the Air Force (Gehirnforschungsstelle der Luftwaffe) under Hugo Spatz at the KWI for brain research, failed to induce electroencephalographic seizure activity in adult epileptic patients from sanatoriums and hospitals who were induced into a hypoxemic state. ${ }^{18}$ Nachtsheim and his assistant Gerhard Ruhenstroth-Bauer thought they could "relativize" Gremmler's work however, by showing that in a more severe hypoxemic state (ie, under low pressure), the children would have seizures..$^{18}$ Additionally, the animal model would be more impressive and applicable if shown that children responded to low pressure as did the epileptic rabbits. ${ }^{18}$ Nachtsheim wrote, "Elsewhere it has been proved for humans that adult epileptics do not respond to oxygen deprivation with an attack. Since a significant difference in the behavior of mature and young epileptics was yielded in our animal experiments, we tested epileptic children at low pressure in a similar manner." ${ }^{18}$ Nachtsheim used at least six epileptic children (four hereditary, two symptomatic) from the Brandenburg (Görden) euthanasia center, and they did not have seizures in response to a low pressure equivalent of $4-6,000$ meters. Nachtsheim still believed he could make true epileptics have seizures, but "the children tested by us were between 11 to 13 years-old, which corresponds to an age of five to six months in rabbits. However, epileptic rabbits five to six months old no longer show the same readiness to react under low pressure as animals two to three months old, which nearly always had seizures. We would still have to test epileptic children five to six years-of-age, though at the moment that is not possible since this age group is not represented in Görden."17-18 His experiment was paradoxical in that the human experiment was meant to confirm his animal experiment, which was originally done to obviate a human experiment. ${ }^{18}$

Of the children involved in Nachtsheim's experiments, only one survived the Nazi regime. ${ }^{18}$ Despite the fact that none of the children died or was injured from these experiments, the children were needlessly placed at considerable risk for injury or death. ${ }^{18}$ Nachtsheim knew of the violent, often fatal, convulsions his epileptic rabbits had at low pressure and expected the children to have similar attacks. ${ }^{18}$ Additionally, adult aviation medicine research at the time had revealed deleterious low pressure effects on the human body especially at 6000 meters. There were also likely significant psychological effects of being locked in a sealed pressure chamber, which may have been even more severe for children. ${ }^{18}$ The low pressure design was of questionable necessity given Gremmler's prior design simply with hypoxemia and not low pressure. ${ }^{18}$ Ruhenstroth-Bauer later justified the risks by claiming that he, Nachtsheim, and an Air Force physician were present at all times to tend to the patients. But the fact remains that the children were still placed in harm's way. ${ }^{18}$ Nachtsheim wrote, "For the clinician working on patients experimentally, the possibilities are always restricted, for he has to take the welfare of his patients into consideration. Only in exceptional cases will a researcher dare to perform an experiment on a patient in the interest of future patients, the outcome of which cannot be predicted with any certainty. Here a method assists the field of medicine, which allows these difficulties to be circumvented at least for a few genetic illnesses, the model experiment on animals." ${ }^{18}$ After the war, Nachtsheim helped in the establishment of human genetics in Germany, and in 1961 he was expert adviser to the Restitution Committee for people sterilized against their will by the Nazis. ${ }^{17}$ $\mathrm{He}$ defended the Nazi sterilization law, and recommended against a right of financial redress for these people.$^{19}$ Since his death, the Society for Anthropology and Human Genetics awards two "Hans Nachtsheim Prizes" for achievements in human genetics. ${ }^{17}$

Viktor von Weizsäcker (1886-1957) - A clinical neurologist and neuropsychiatrist who was influenced by the neurologist William Heinrich Erb ${ }^{e}$ while studying in Heidelberg. He was a member of the American Psychosomatic Society, and ironically "because of a concern for his fellow man" he admired Sigmund Freud (a rare attitude among Germans). ${ }^{20-21} \mathrm{He}$ became Chair of Neurology at Heidelberg in 1920, and later chair of Neurology and Psychiatry at the Neurological Research Institute of Breslau University. Though there is no direct documentation of his knowledge of or involvement in the activities, brains from children killed at the Loben/Lubliniecz hospital in the euthanasia program were regularly sent to Breslau for research. ${ }^{12,16}$ As mentioned previously, Scherer conducted his neuropathological studies on murdered children at Breslau. ${ }^{1-3}$ Von Weizsäcker believed in "antimechanistic new healing," but he "never was able to differentiate between therapy and destruction, only between justified and unjustified destruction."21 Von Weizsäcker expressed the belief of many when he stated "For quite a number of doctors... Hitler not only had the power of a commander in chief in a political sense, but was also the highest ranking physician." $22 \mathrm{He}$ stated there was "sacrifice by common consent," thus acknowledging the collective responsibility of all involved in the euthanasia program. ${ }^{6}$ After the war he denounced Nazi medical crimes ${ }^{21}$ and was involved as scientific assistant in the German medical delegation at the Nuremberg Medical Crimes Trial of $1946-47 .{ }^{19} \mathrm{He}$ wrote in favor of reflecting on the past on a high ethical level, and firmly rejected the usage of the term "euthanasia" instead of "murder."19

\section{Discussion}

German medicine was the envy of Western society and producer of eight Nobel laureates prior to 1939. How could Germany's neuroscientists be capable of such criminal savagery? Their immoral and unethical actions were in direct violation of the Nuremberg ethics code of 1931 and the Hippocratic Oath. ${ }^{1}$ All of the scientists were heavily influenced by racial eugenics beliefs, and neuroscience was just a microcosm of the Nazi totalitarian state. ${ }^{6}$ Nachtsheim was not concerned with the interest of the individual but the collective 
German "Volk," which was to identify epileptics and prevent their spread of "deviant mutations." 17 His treatment of child epileptics not as humans but as "subjects" or "material" similar to his rabbits in the low pressure experiments was not a large transformation in moral status considering at least 100000 patients had already been euthanized. ${ }^{18}$ Schneider's psychiatric idealism allowed him to become indoctrinated in Nazi ideology that espoused euthanasia, especially when he was granted large sums of money to conduct research and given significant power and prestige by his role. ${ }^{15}$ For Hallervorden and Spatz "the quest for scientific discovery had become an all-consuming passion." Hallervorden had doubts on legality, but was so blinded by ambition and intellectual curiosity that he could not see the bigger picture that his work lent moral legitimacy to Action T4. ${ }^{6,23}$ Indeed, the work of eminent neuroscientists may have justified the euthanasia programs even more than eugenics did. ${ }^{4,9}$

There was a symbiotic relationship between the Nazis and doctors: the doctors craved power and prestige, and their medical authority validated Nazi beliefs in the applied biology theories of racial hygiene.' Being a loyal Nazi led to more access to research grants and job opportunities, ${ }^{16}$ as seen in the case of Ostertag ${ }^{14}$ and Schneider. ${ }^{5,15}$ Indeed by 1937 doctors constituted seven times more of the Nazi party than other employed male groups. By $1942,50 \%$ of all German physicians were members of the Nazi party or had roles in Nazi government or universities. ${ }^{1,6-7} \mathrm{At}$ least 350 doctors behaved criminally, though only 23 were tried at the Nuremberg Medical Crimes Trial in 1946-7. Thus, two myths are debunked: i) that only a fringe element in science was guilty of Nazi war crimes; ii) that the crimes were only committed in concentration camps. ${ }^{7}$

It is ironic that Scherer, Hallervorden, Spatz, and Scholz did not share the sentiment or compassion of their mentor, teacher, and colleague Walther Spielmeyer (1879-1935), ${ }^{2-4}$ who actively spoke out against the Nazi regime at great personal risk, and assisted in helping German neuroscientists to emigrate and settle outside of Germany. ${ }^{2,10}$ Other neuroscientists spoke out as well, ${ }^{1-}$ ${ }^{3}$ and there was no law requiring the participation or cooperation with Nazi policies or programs. ${ }^{6}$ These latter neuroscientists understood that "knowledge, although important, may be less important to a decent society than the way it is obtained." "Those who spoke out during this period ultimately and unfortunately had their voices drowned out, and the unethical experimentation and killing continued.

\section{Conclusions}

The crimes committed by the neuroscientists during the Nazi era are explained by indoctrination in eugenics and Nazi applied biology theories, misguided scientific and therapeutic idealism, and opportunism for power and prestige, career placement, and research money. Logic would dictate that we can judge these complex individuals with complex motivations only in respect to their peers and to the complicated times in which they lived. However, there seems to be a clear distinction between the moral and ethical character of neuroscientists who participated or collaborated, despite the lack of laws requiring them to do so, and the neuroscientists who resisted the Nazis and upheld the Hippocratic Oath and medical ethics codes of the time. The experience and success of the Nazi "euthanasia" programs is believed to have led to the Final Solution to the Jewish Question and the murder of six million Jews, ${ }^{16}$ along with the murder of millions of other "undesirables" including homosexuals, communists, Gypsies, Slavs, and prisoners of war. ${ }^{24}$ Obviously, the actions of scientists can directly or indirectly precipitate genocide. Medical experimentation on humans occurred in the US as well throughout the 20th century including after World War II and the 1946 Nuremberg Code. ${ }^{1}$ As neuroscientists, we cannot be comforted that the slippery slope seen in Nazi Europe will never happen again. We must have constant vigilance and responsibility to uphold the main tenet of the Hippocratic Oath, "I will do no harm or injustice to them." 25

\section{ACKNOWLEDGMENTS}

The author thanks Prof. Dr. Heinz Schott of the Medizinhistorisches Institut der Universität Bonn for his assistance regarding Viktor von Weizsäcker; Susanne Uebele at the Archiv der Max-Planck-Gesellschaft in Berlin-Dahlem, and Dawn McInnis at the Clendening History of Medicine Library, University of Kansas Medical Center, for photo assistance. The author acknowledges the website www.whonamedit.com for assistance in searching for names of some of the neuroscientists during this era, listing some obscure eponyms, and providing further references.

\section{REFERENCES}

1. Cohen MM Jr. Genetic drift: overview of German, Nazi, and Holocaust medicine. Am J Med Genet A. 2010;152A(3):687-707.

2. Kondziella D. Thirty neurological eponyms associated with the Nazi era. Eur Neurol. 2009;62(1):56-64.

3. Strous RD, Edelman MC. Eponyms and the Nazi era: time to remember and time for change. Isr Med Assoc J. 2007;9(3): 207-14.

4. Hughes JT. Neuropathology in Germany during World War II: Julius Hallervorden (1882-1965) and the Nazi programme of 'euthanasia'. J Med Biogr. 2007;15(2):116-22.

5. Burleigh M. 'Wheels must roll for victory!' Children's 'euthanasia' and 'Action T4.' In: Death and deliverance: 'Euthanasia' in Germany c. 1900-1945. Cambridge, UK: Cambridge University Press; 1994. p. 93-129.

6. Shevell M. Racial hygiene, active euthanasia, and Julius Hallervorden. Neurology. 1992;42(11):2214-19.

7. Shevell MI. Neurosciences in the Third Reich: from Ivory Tower to death camps. Can J Neurol Sci. 1999;26(2):132-8.

8. Lifton RJ. "Euthanasia": Direct medical killing. In: The Nazi doctors: Medical killing and the psychology of genocide, 2nd edition. New York: Basic Books; 2000. p. 45-79.

9. Shevell MI, Peiffer J. Julius Hallervorden's wartime activities: implications for science under dictatorship. Pediatr Neurol. $2001 ; 25(2): 162-5$.

10. Firkin BG, Whitworth JA. Dictionary of medical eponyms. Boca Raton, FL: Parthenon Publishing Group; 2002.

11. Max Planck Institute of Psychiatry (German Research Institute of Psychiatry). [History of the Institute page on the Internet]. Munich: Max Planck Institute of Psychiatry; c2011 [updated 2011; cited 2011 Jan 25]. Available from: http://www.mpipsykl. mpg.de/en/institute/history/index.html.

12. Aly G. Pure and tainted progress. In: Aly G, Chroust P, Pross C, editors. Cleansing the Fatherland: Nazi medicine and racial hygiene. Baltimore: Johns Hopkins University Press; 1994. p. $156-237$.

13. Klatzo I, Rhein GZ. Transfer to a small arena: Neustadt before and during the war. In: Klatzo I, Rhein GZ. Cécile and Oskar Vogt: The visionaries of modern neuroscience. New York: SpringerVerlag Wien; 2002. p. 59-63. 
14. Peiffer J. Neuropathology in the Third Reich: Memorial to those victims of National-Socialist atrocities in Germany who were used by medical science. Brain Pathol. 1991;1:125-31.

15. Lifton RJ. Participants. In: The Nazi doctors: medical killing and the psychology of genocide, 2nd edition. New York: Basic Books; 2000. p. 103-33.

16. Friedlander $\mathrm{H}$. Toward the killing pause. In: The origins of Nazi genocide: from euthanasia to the final solution. Chapel Hill: University of North Carolina Press; 1995. p. 111-35.

17. Deichmann U. The Content and result of research at Kaiser Wilhelm Institutes. In: Biologists under Hitler (translated by Thomas Dunlap). Cambridge, Mass: Harvard University Press; 1996. p. 206-50.

18. Schmuhl H-W. In the realm of opportunity: The Kaiser Wilhelm Institute for Anthropology, Human Heredity, and Eugenics during World War II: 1938/42-1945. In: The Kaiser Wilhelm Institute for Anthropology, Human Heredity, and Eugenics, 1927-1945: Crossing Boundaries. Springer: Göttingen; 2008. p. 241-408.

19. Peiffer J. Phases in the postwar German reception of the "euthanasia program" (1939-1945) involving the killing of the mentally disabled and its exploitation by neuroscientists. J Hist Neurosci. 2006;15(3):210-44.
20. Binger, C. In Memoriam: Viktor von Weizsäcker. Psychosom Med. 1957;19 (4):265-6.

21. Kater MH. Conclusion: The crisis of physicians and medicine under Hitler. In: Doctors under Hitler. Chapel Hill: University of North Carolina Press; 1989. p. 222-40.

22. Lifton RJ. "Wild euthanasia": The doctors take over. In: The Nazi doctors: medical killing and the psychology of genocide, 2nd edition. New York: Basic Books; 2000. p. 96-102.

23. Pross C. Nazi doctors, German medicine, and historical truth. In: Annas GJ, Grodin MA, editors. The Nazi doctors and the Nuremberg Code: Human rights in human experimentation. Oxford: Oxford University Press; 1992. p. 32-52.

24. Proctor R. The destruction of "lives not worth living." In: Racia hygiene: Medicine under the Nazis. Cambridge, Mass: Harvard University Press; 1988. p. 177-222.

25. The National Library of Medicine, National Institutes of Health [The Hippocratic Oath page on the Internet]. Bethesda, Maryland: National Library of Medicine; c2010 [updated 24 June 2010; cited 2011 Jan 25]. Available from: http://www.nlm. nih.gov/hmd/greek/greek_oath.html. 